\title{
EVOLUSI ANTAR SPECIES (LELUHUR SAMA DALAM PERSPEKTIF PARA PENENTANG)
}

\author{
Helmi \\ Fakultas Keguruan dan IImu Pendidikan Universitas Djuanda Bogor \\ E-mail: helmia.suwarjono@gmail.com
}

\begin{abstract}
Abstrak
Sejarah evolusi telah melewati perjalanan yang panjang. Para saintis dan filsuf banyak mengalami perdebatan dalam situasi yang kompleks, akan tetapi salah satu masalah inti dari perbedaan pandangan adalah permasalahan peralihan yang diklaim dapat terjadi antar spesies. Begitu banyak ilmuan yang membantah akan hal ini dari sudut pandang kepercayaan maupun dari fakta ilmiah yang dapat dibuktikan. Para penentang ini merupakan ahli Creationisme atau orang-orang yang percaya akan fakta penciptaan. Mereka mengemukakan berbagai alasan mengapa evolusi antar spesies merupakan hal yang mustahil. Diantara penentang adalah Samuel Wilberforce yang merupakan seorang pendeta, la mengkritik dan menentang keras The Origin Of Species By Means Of Natural Selection yang mengungkapkan kemungkinan bahwa manusia dan kera memiliki nenek moyang yang sama. Bantahan selanjutnya datang dari ahli Genetika dan hukum pewarisan sifat yaitu Gregor Mendel. Penemuan Mendel seharusnya menghempaskan teori evolusi Darwin yang dipengaruhi oleh Lamarck kepada krisis yang akut, jika para penerus Darwin tidak segera melakukan revisi untuk membuat penyesuaian. Penentangan yang keras terus berlanjut dari berbagai kalangan dan ahli sains diantaranya seorang ahli anatomi dan paleontology bernama Georges Cuvier serta seorang cendikiawan muslim Adnan Oktar atau lebih dikenal dengan sebutan Harun Yahya.
\end{abstract}

Kata kunci: Evolusi, Species, Para Penentang.

\section{PENDAHULUAN}

Evolusi merupakan ilmu yang banyak menuai kritik hingga saat ini. Pandangan pro dan kontra mengikuti perjalanan evolusi dan perkembangan ya. Meskipun posisi Darwin telah dianggap berjasa dalam perkembangan ilmu mengenai asal usul kehidupan di bumi akan tetapi penyangkalan dan pencarian bukti-bukti ilmiah akan kedangkalan teori yang dicetuskan Darwin bermunculan dari berbagai penjuru dunia. Meskipun demikian, berdiri pada sisi yang sebaliknya, begitu banyak ilmuan yang mendukung dan mengajarkan kebenaran teori Darwin. Kontroversi akan selalu ada, bahkan di Negara sekuler seperti Amerika pun setelah 150 tahun diterbitkan teori evolusi tetap saja menjadi sumber perdebatan (Barone, Petto \& Campbell, 2014). Akan tetapi mempelajari dan mengikuti perkembangan pemikiran dan penemuan dalam ilmu pengetahuan adalah cara dimana ilmu itu sesungguhnya didapatkan.

Didalam pemikiranya sebagai seorang saintis, Darwin kaya akan ilmu yang dipelajarinya selama pejalananya mengikuti pelayaran Beagle pada tahun 1832 dan Darwin kemudian ikut mengarungi penjuru dunia selama lima tahun. Darwin muda begitu kagum akan beragam spesies makhluk hidup, terutama jenis-jenis burung finch tertentu di kepulauan Galapagos. Ia menduga bahwa variasi pada paruh burung- burung tersebut disebabkan oleh kemampuan adaptasi hewan terhadap habitat. melalui pemikiran ini, ia menduga bahwa asal usul kehidupan dan spesies berdasar pada konsep "adaptasi terhadap lingkungan". Menurut Darwin, aneka spesies makhluk hidup tidak diciptakan secara terpisah oleh Tuhan, tetapi dari nenek moyang yang satu dan menjadi berbeda antara satu dengan yang lainya akibat kondisi alam. Darwin banyak menulis pemikiran-pemikiranya melalui karya- karyanya dibidang sains.

Istilah evolusi muncul untuk pertama kali didalam pengertian ilmiah modern oleh seorang Geologis berkebangsaan Skotlandia bernama Charles Lyell tahun 1832. Selanjutnya Charles Darwin kemudian menggunakan istilah ini satu kali dalam paragraf penutup bukunya yang berjudul On The Origin of Species (Asal mula Spesies) pada tahun 1859. Kata evolusi ini kemudian dipopulerkan 
oleh Herbert Spencer dan ahli biologi lainnya. Seorang ahli filsafat bernama Herbet Spencer yang berasal dari Inggris untuk pertamakali menuliskan istilah evolusi. Menurut Spencer dalam bukunya "Social Static", konsep evolusi sangat berkaitan dengan perkembangan ciri atau sifat dari waktu ke waktu melalui perubahan bertingkat (Bertenz, 1975). Pengertian yang dikemukakan oleh Spencer tersebut memperlihatkan kejadan suatu proses perubahan. Akantetapi, tampak bahwa pengertian yang dimaksud tidak terkait dengan kajian biologi, dan pada perkembangannya istilah tersebut tenggelam bersamaan dengan perkembangan pemikiran para ahli filsafat yang lain.

Evolusi dimasa kini berkembang dari ilmu tentang asal mula kehidupan manusia menjadi hal yang baru mengarah kepada kata perubahan, tidak hanya mengenai asal usul makhluk hidup, pada bidang ilmu yang lainya kata evolusi juga digunakan. Tidak banyak pertentangan mengarah kepada evolusi sebagai perubahan yang terjadi secara berangsur-angsur dalam waktu yang lama, akan tetapi beberapa konsep awal yang dicetuskan Darwin dalam karyanya The origin of species memberikan jejak kuat yang melatar belakangi pembantahan. Salah satu hal yang menjadi perdebatan adalah permasalahan leluhur sama dalam pandangan Darwin kepada asal mula semua spesies yang terdapat dibumi.

Pada sisi pandangan pribadinya yang berasal dari pemikiran dari hasil petualangan ya Darwin mengatakan bahwa semua makhluk hidup dibumi berasal dari leluhur yang sama yaitu makhluk hidup bersel satu. Pandangan ini yang kemudian menjadi polemik, kaum agamis dan golongan lain yang tidak sependapat kemudian mengeluarkan beragam argumentasi yang ilmiah maupun tidak ilmiah untuk menyangkal pendapat tersebut. Sebagian beranggapan bahwa teori Darwin adalah filsafat yang menyesatkan umat manusia.

Evolusi dan segala macam kandunganya mendapatkan kritikan yang tajam dikarenakan ini adalah ilmu yang tidak prediktif. Bagaimanapun, disamping beberapa argumentasin ya yang terbantahkan dan dievaluasi oleh beberapa pembaharu, namun tidak dapat dipungkiri bahwa Darwin memberikan kontribusi besar bagi awal mula pencarian mendalam mengenai asal usul kehidupan manusia yang pada akhirnya melahirkan penemuan-penemuan baru, ilmu-ilmu baru, pemikiranpemikiran baru dibidang sains dan kehidupan manusia dibumi.

The origin of species by means of natural selection karya Darwin adalah sebuah buku yang memiliki daya magis, menginspirasi dan menjadi perbincangan. Dalam kurun waktu yang panjang, telah bayak terlahir ilmuan yang terinspirasi dari karya monumental Charles Robert Darwin ini. Beberapa dari mereka bahkan mendedikasikan kehidupan dan pemikiran ya untuk menguji, mengembangkan dan mengajarkan buku ini. Bentuk asli dari buku fenomenal ini dapat kita lihat pada gambar 1.

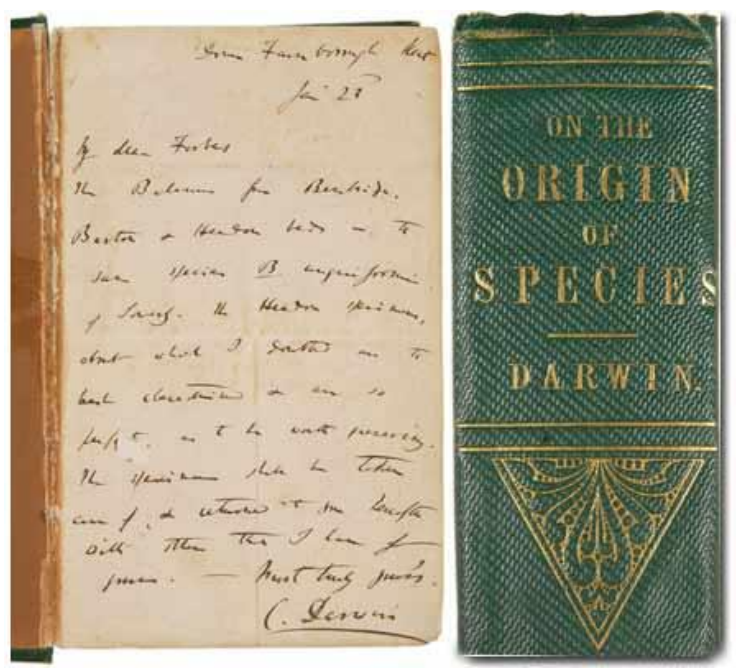

Gambar 1. The Origin Of Species

Pada gambar 1 diatas, dapat kita lihat tulisan asli dari Charles Darwin pada buku The Origins. Buku ini adalah salah satu buku sains penting yang pernah dibuat oleh para pemikir dibidang sains 
(Park, 2012).

Banyak orang tidak ingin memandang segala sesuatu dari berbagai sudut, tidak banyak orang yang terbuka akan ilmu pengetahuan, menjadi individualis sehingga apa yang dipandangn ya dan diyakininya adalah kebenaran apa yang tanpa cacat dan tidak mau memandang kemungkinankemungkinan lain yang berbeda dengan pemikiranya. Karenanya dirasa perlu untuk memandang evolusi dai berbagai sisi termasuk ketika ada sisi dimana banyak ilmuan dan ahli menentangnya. Memandang dari sisi lain yang boleh jadi tidak sepemikiran akan menjadikan kita bijak dan adil terhadap situasi apapun termasuk ilmu pengetahuan. Berdasarkan semua latar belakang yang diuraikan diatas,kajian ini tidak bertujuan untuk memberikan pengadilan terhadap konsep- konsep yang diketengahkan oleh Darwin, akan tetapi hanya memaparkan pemahaman akan "Leluhur yang sama" dalam ilmu evolusi dari sisi para ilmuan dan ahli yang menentangnya.

\section{METODE}

Penelitian ini merupakan hasil deskripsi yang bersumber dari kajian terhadap pustaka. Kajian dilakukan terhadap buku, jurnal dan sumber lain yang relevan dan dapat dijamin keabsahanya.

\section{PEMBAHASAN}

\section{AWAL MULA KEHIDUPAN DI BUMI}

\section{Pemikiran Darwin}

Charles Robert Darwin menulis pemikirannya yang terjadi disepanjang pelayaran ya dengan kapal Beagle. Akan tetapi tulisan panjang yang dibuatnya tidak serta merta dipublikasikan olehnya. Ketika kepulangan ya ke Britania Raya di tahun 1836 Darwin memahami bahwa antara asal mula spesies dengan adaptasi terhadap lingkungan ada keterkaitan yang erat.

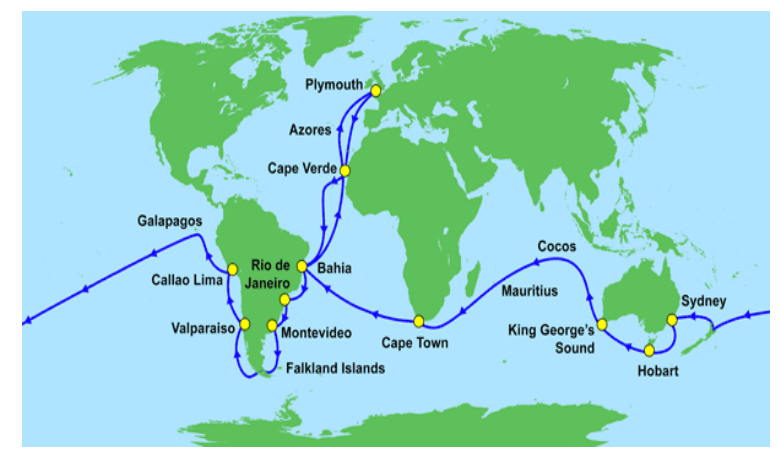

Gambar 2. Peta pelayaran Beagle

Tulisan panjang tersebut kemudian hanya disimpan olehnya dan merasa segan untuk mempublikasikanya kepada orang ban yak karena khawatir akan dampak keributan yang akan ditimbulkan akibat pemikiranya itu (Campbell, 2003). Akan tetapi atas anjuran dan desakan dari temanya seorang saintis berkebangsaan inggris bernama Charles Lyell, Darwin kemudian menerbitkan bukun ya. Sudah diketahui secara umum bahwa intisari tulisan Darwin yang kemudian menjadi popular adalah terhadap 2 hal, yakni: 1) Spesies yang hidup sekarang merupakan evolusi dari spesies yang hidup sebelumnya, 2) Cara terjadinya evolusi adalah melalui seleksi alam. Akan tetapi Darwin tidak menyebutkan atau kemungkinan dia sendiri tidak mengetahui bahwa ilmu pengetahuan yang berkembang memperoleh sebab-sebab lain akan dasar terjadinya evolusi. Diantaranya genetic drift, mutasi, gen flow, perkawinan tidak acak, dan seleksi alam. Darwin menyatakan kesamaan leluhur memiliki makna bahwa manusia memiliki nenek moyang yang sama dengan binatang yang lain. Darwin menyatakan bahwa semua makhluk hidup yang memiliki ciri yang sama atau homolog berasal dari leluhur yang sama dan evolusi menjadikan mereka berlainan pada saat ini. Darwin mengatakan bahwa makhluk hidup berasal dari awal yang 
tunggal. Awal yang tunggal ini adalah makhluk hidup bersel satu yang terdiri dari asam amino dan air. Akan tetapi Darwin tidak pernah menuliskan dalam karya-kar yan ya yaitu The Descent of Man, Selection in Relation to Sex dan The Expression of the Emotions in Man and Animals serta karya yang lain ya akan semua penyebab ini.

\section{Kehidupan pra Adam (Pre-Adamete)}

Konsep pra-Adam merupakan solusi yang dicetuskan oleh para ahli masa itu untuk menjelaskan pluralitas manusia yang ada saat ini. Konsep pra-Adam memberikan penjelasan mengenai keberadaan manusia sebelum Adam turun ke bumi. Para ahli percaya bahwa konsep pra- Adam merupakan jawaban dari keberagaman bentuk fisik manusia. Konsep praAdam terus mengalami perkembangan dari waktu ke waktu, perkembangan pengetahuan berpengaruh pada pemikiran para ahli dalam mengambil sikap dan mengembangkan teori. Isabelle Duncan adalah orang yang pertama kali menggunakan kata pre-adamite man pada tahun 1860an. Melalui bukunya yang berjudul Pre- Adamite Man, Isabelle mengungkapkan pemikiranya. Pemikiran ini diinspirasi dari kitab Injil yang menceritakan tentang adanya dua penciptaan. Ketika manusia ditempatkan dibumi dalam penciptaanya namun han ya ras kedua yang merupakan leluhur manusia sekarang. Duncan berusaha men yatukan antara penceritaan Injil dan ilmu pengetahuan (Snobelen, 2001). Isabelle Duncan mengutarakan pemikirannya mengenai konsep pra-Adam dalam bukunya yang berjudul Pre-adamite Man yang membahas konsep pra- Adam dengan latar belakang teologi. Teori evolusi Darwin menyoroti konsep praAdam dari metodologi biologi yang menjelaskan bahwa asal usul makhluk hidup mungkin berasal dari awal yang tunggal. Konsep pra- Adam pun tetap dibahas oleh para antropologi ragawi, serta para ahli arkeologi sebagai bagian dari perjalanan kontroversi kemunculan manusia di bumi.

\section{Species dan spesiasi}

Spesies berasal dari bahasa latin yang artinya jenis atau penampakan. Spesies adalah unit populasi terbesar dimana pertukaran genetic mungkin terjadi dan terisolasi dari poulasi yang lain ya secara genetik. Sedangkan spesiasi adalah pembentukan spesies baru. Menurut Mayr setiap organism memiliki tiga sifat yaitu: (1) dapat men yesuaikan diri dengan lingkungan, (2) dapat hidup berdampingan dengan spesies yang berbeda, (3) tidak dapat melakukan perkawinan dengan spesies lainya (Sugiri, 1988). Tahun-tahun setelah publikasi The Origin, saintis jatuh bangun berupa ya memberikan penjelasan dan pencerahan bagaimana proses terus menerus hingga kelompok makhluk hidup dikenal dengan sebutan spesies (Coyne, 2009). Mari kita simak pern yataan Darwin tentang spesies dan variasi. Darwin mengatakan bahwa spesies adalah varietas, ada kemungkinan Darwin ingin menyampaikan bahwa spesies dan varietas adalah berbeda dalam tingkatan. Lebih lanjut Darwin berpendapat bahwa varietas adalah spies yang sedang berproses menuju pembentukan. Hal ini sungguh membingungkan antara kebenaran atau kebingungan yang menyesatkan bergantung orang yang memaknain ya. Karena sejatinya variasi dalam spesies merupakan perbedaan dalam spesies (Sugiri, 1988). Perbedaan antar spesies dan perbedaan didalam spesies adalah hal yang sungguh sangat berbeda. Pada kenyataanya teori seleksi alam tidak sesederhana apa yang ada dalam pemikiran Darwin kala itu. Argument yang sering diajukan oleh para peneliti adalah teori evolusi Darwin telah mengembangkan konsepsi kita mengenai kekerabatan manusia dan hewan sejatinya menurut Darwin sangat dekat (Kaufman, 2014). 


\section{Perubahan antar species}

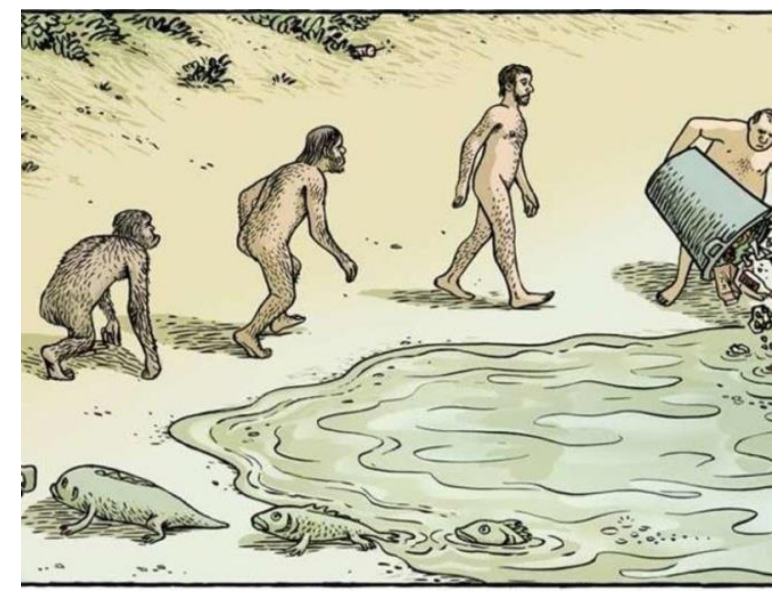

Gambar 3. Perubahan spesies

Teori evolusi menyatakan bahwa semua makhluk hidup yang beraneka ragam di bumi ini berasal dari satu nenek moyang yang sama. Teori ini menyatakan bahwa kemunculan makhluk hidup yang sangat beragam terjadi melalui variasi-variasi kecil dan bertahap dalam rentang waktu sangat lama. Teori ini menyatakan bahwa mulanya makhluk hidup bersel satu terbentuk. Selama ratusan juta tahun kemudian, makhluk bersel satu ini kemudian berevolusi menjadi ikan dan hewan invertebrata (tak bertulang belakang) yang hidup di laut. Ikan-ikan ini kemudian diduga muncul ke daratan dan berubah menjadi reptil. Tampaknya pada saat pen yusunan teorinya, Darwin diilhami oleh para ahli biologi evolusionis sebelumn ya, terutama seorang ahli biologi Prancis, Lamarck. Menurut Lamarck, makhluk hidup mewariskan ciri-ciri yang mereka dapatkan selama hidupnya dari satu generasi ke generasi berikutn ya sehingga terjadilah evolusi.

\section{SEJARAH PENENTANGAN}

Seorang naturalis Inggris bernama Wallace yang juga menciptakan teori seleksi alam (theory of natural selection) yang berbeda dengan Darwin, menolak menerapkan teori seleksi alam diterapkan pada manusia. Wallace menganggap manusia terlalu cerdas, beradab dan canggih sebagai produk seleksi alam semesta. Menurut Wallace kemampuan Homo sapiens bukanlah hasil seleksi alam melainkan campur tangan suatu hal supranatural yang menjadikan manusia modern sedemikian istimewa (Leake y, 2003). Samuel Wilberforce adalah seorang pendeta, dilahirkan pada tahun 1805 dan wafat pada tahun 1873 di Inggris. salah satu tokoh yang memberikan kritikan yang keras terhadap Darwin dan teorinya datang dari Samuel Wilberforce. Dia mengkritik The origin of species terutama mengenai teori tentang seleksi alam. Samuel menentang keras akan kemungkinan bahwa manusia dan berbagai jenis kera memiliki nenek moyang yang sama. Kritikan tajam ia sampaikan pada perdebatan tentang evolusi pada pertemuan British Association pada 30 juni 1960. Perkataan bersejarah yang diungkapkan oleh Samuel ialah bahwa ia akan lebih mudah mengakui bahwa ia adalah keturunan kera daripada ia harus membiarkan ketidak benaran diajarkan.

\section{BUKTI - BUKTI ILMIAH PENENTANGAN}

Sudut pandang keyakinan padamulanya lebih banyak dikenal sebagai alasan yang dikemukakan untuk menolak evolusi, namun selain itu ada pula alasan- alasan lainya yang disandarkan pada bukti-bukti ilmiah yang tidak han ya berisi opini ataupun hal-hal dogma. Secara berbeda justru pembuktian oleh orang-orang berikut ini melahirkan pemikiran sebaliknya bahwa teori evolusi Darwin adalah dogma bagi orang-orang atheis yang ingin menentang Tuhan.
1. George Mendel 
George Mendel merupakan bapak genetika. Penulis dalam hal ini menemukan masih tersedia secara online transkrip journal Eric yang mengangkat materi tentang hukum Mendel diterbitkan pada tahun 1974. Meskipun agak cukup lama dan sudut pandang mungkin sudah jauh berbeda pada saat sekarang ini, akan tetapi artikel ini masih sangat mungkin kita baca dan dalami bagaimana pandangan orang pada saat itu mengenai hukum Mendel.

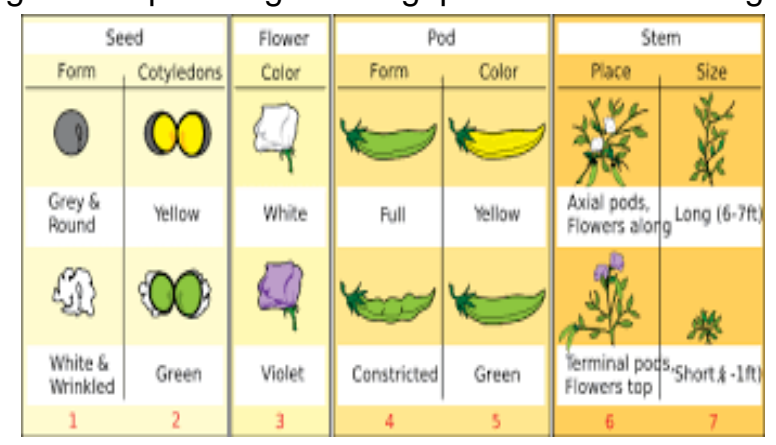

Gambar 4. Hukum Mendel

Pada mulan ya ban yak orang yang merasa bingung dengan pernyataan Mendel mengenai pewarisan sifat untuk diterapkan pada manusia padahal Mendel sendiri membuktikanya melalui percobaan kacang Polong (Spencer, 1974). Kemunculan hukum Mendel seharusnya meruntuhkan teori evolusi. Hukum Mendel telah memposisikan Darwinisme pada keadaan yang genting. Karenan ya kemudian, para ilmuwan pendukung Darwinisme bersepakat mengembangkan suatu rumusan evolusi lain di perempat pertama abad ke-20. Kemudian lahirlah "neo-Darwinisme" atau pembaharu Darwin. Karenan ya disini kita hendakn ya meluruskan kesalah pahaman umum terkait hukum Mendel dan Evolusi. Mendel tak hanya menentang model evolusi Lamarck, tetapi juga Darwin. seperti yang dia tuliskan dalam karyanya berjudul "Mendel's Opposition to Evolution and Darwin" Penentangan Mendel atas Evolusi dan Darwin] yang dipublikasikan dalam Journal of Heredity. Dijelaskan bahwa Mendel sangat memahami The Origin of Species [Asal Usul Spesies] dan ia menentang teori Darwin; Darwin mendukung munculnya keturunan dengan perubahan melalui seleksi alam, sedangkan Mendel mendukung keyakinan agama tentang penciptaan khusus." (Yahya, 1994). Para IImuwan yang bersikeras menyatukan Darwinisme dengan ilmu genetika, dengan berbagai cara mereka kemudian berkumpul dalam sebuah pertemuan yang diadakan oleh the Geological Society of America (Perkumpulan Masyarakat Geologi Amerika) pada tahun 1941. Setelah pembicaraan panjang, mereka setuju pada kesepakatan untuk membuat penjelasan baru tentang Darwinisme; dan beberapa tahun setelah itu, para ahli menghasilkan sebuah sintesis [rumusan hasil perpaduan] dari erbagai bidang mereka menjadi sebuah teori evolusi yang telah diperbaharui.Para ilmuwan yang berperan serta dalam membangun teori baru ini termasuk ahli genetika G. Led yard Stebbins dan Theodosius Dobzhansky, ahli ilmu hewan Ernst Ma yr dan Julian Huxley, ahli paleontologi George Gaylord Simpson dan Glenn L. Jepsen, dan ahli genetika matematis Sir Ronald A. Fisher dan Sewall Wright.Untuk menyanggah fakta "stabilitas genetik" (genetic homeostasis), kelompok ilmuwan ini menggunakan gagasan "mutasi", yang telah diperkenalkan oleh ahli botani Belanda Hugo de Vries pada awal abad ke-20. Mutasi adalah kerusakan yang terjadi, untuk alasan yang tidak diketahui, dalam mekanisme penurunan sifat pada makhluk hidup. Organisme yang mengalami mutasi memperoleh bentuk yang tidak lazim, yang menyimpang dari informasi genetik yang mereka warisi dari indukn ya. Konsep "mutasi acak" diharapkan bisa menjawab pertan yaan tentang asal usul variasi [keragaman] menguntungkan yang menyebabkan makhluk hidup berevolusi sesuai dengan teori Darwin—sebuah kejadian yang Darwin sendiri tidak bisa menjelaskann ya, tetapi hanya mencoba menghindarin ya dengan mengacu kepada teori Lamarck. Kelompok The Geological Societ y of America [Perkumpulan Masyarakat Geologi Amerika] menamai teori baru ini, yang dirumuskan dengan menambahkan gagasan mutasi pada teori seleksi alam Darwin, sebagai "teori evolusi sintesis" atau "sintesis modern". Dalam 
waktu singkat, teori ini menjadi dikenal dengan nama "neo-Darwinisme" dan pendukungn ya sebagai "neo-Darwinis." Namun terdapat sebuah masalah besar: Memang benar bahwa mutasi mengubah informasi genetik makhluk hidup, tetapi perubahan ini selalu terjadi dengan dampak merugikan makhluk hidup bersangkutan. Semua mutasi yang teramati menghasilkan makhluk yang cacat,lemah, atau berpenyakit dan, kadangkala, membawa kematian pada makhluk tersebut. Oleh karena itu, dalam upaya untuk mendapatkan contoh "mutasi-mutasi menguntungkan" yang memperbaiki informasi genetik pada makhluk hidup, neo-Darwinis melakukan banyak percobaan dan pengamatan. Selama puluhan tahun, mereka melakukan percobaan mutasi pada lalat buah dan berbagai spesies lainnya. Namun tak satu pun dari percobaan ini memperlihatkan mutasi yang memperbaiki informasi genetik pada makhluk hidup. Saat ini permasalahan mutasi masih menjadi kebuntuan besar bagi Darwinisme. Meskipun teori seleksi alam menganggap mutasi sebagai satu-satunya sumber dari "perubahan menguntungkan", tidak ada mutasi dalam bentuk apa pun yang teramati yang benar-benar menguntungkan (yaitu, yang memperbaiki informasi genetik). Setelah pembicaraan yang panjang, kelompok pro Darwin membuat penjelasan baru tentang Darwinisme dan beberapa tahun setelah itu, para ahli menghasilkan pembaharuan mengenai Darwinisme. Kaum ini terdiri atas ahli genetika G.Led yard Stebbins dan Theodosius Dobzhansky, ahli ilmu hewan Ernst Mayr dan Julian Huxley, ahli paleontologi George Ga ylord Simpson dan Glenn L. Jepsen, dan ahli genetika matematis Sir Ronald A. Fisher dan Sewall Wright. Untuk menyanggah fakta "stabilitas genetik" (genetic homeostasis), kelompok ilmuwan ini menggunakan gagasan "mutasi", yang telah diperkenalkan oleh ahli botani Belanda Hugo de Vries pada awal abad ke-20. Mutasi adalah kerusakan yang terjadi, untuk alasan yang tidak diketahui, dalam mekanisme penurunan sifat pada makhluk hidup. Organisme yang mengalami mutasi memperoleh bentuk yang tidak lazim, yang menyimpang dari informasi genetik yang mereka warisi dari induknya. Konsep "mutasi acak" diharapkan bisa menjawab pertan yaan tentang asal usul variasi [keragaman] menguntungkan yang men yebabkan makhluk hidup berevolusi sesuai dengan teori Darwinsebuah kejadian yang Darwin sendiri tidak bisa menjelaskann ya, tetapi hanya mencoba menghindarinya dengan mengacu kepada teori Lamarck. Kelompok The Geological Society of America [Perkumpulan Masyarakat Geologi Amerika] menamai teori baru ini,yang dirumuskan dengan menambahkan gagasan mutasi pada teori seleksi alam Darwin, sebagai "teori evolusi sintesis" atau "sintesis modern". Dalam waktu singkat, teori ini menjadi dikenal dengan nama "neoDarwinisme" dan pendukungn ya sebagai "neo-Darwinis." Namun terdapat sebuah masalah besar: Memang benar bahwa mutasi mengubah informasi genetik makhluk hidup, tetapi perubahan ini selalu terjadi dengan dampak merugikan makhluk hidup bersangkutan. Semua mutasi yang teramati menghasilkan makhluk yang cacat,lemah, atau berpenyakit dan, kadangkala, membawa kematian pada makhluk tersebut. Oleh karena itu, dalam upaya untuk mendapatkan contoh "mutasi- mutasi menguntungkan" yang memperbaiki informasi genetik pada makhluk hidup, neo-Darwinis melakukan banyak percobaan dan pengamatan. Selama puluhan tahun, mereka melakukan percobaan mutasi pada lalat buah dan berbagai spesies lainnya. Namun tak satu pun dari percobaan ini memperlihatkan mutasi yang memperbaiki informasi genetik pada makhluk hidup. Saat ini permasalahan mutasi masih menjadi kebuntuan besar bagi Darwinisme. Meskipun teori seleksi alam menganggap mutasi sebagai satu-satunya sumber dari "perubahan menguntungkan", tidak ada mutasi dalam bentuk apa pun yang teramati yang benar-benar menguntungkan (yaitu, yang memperbaiki informasi genetik) hingga sejauh ini.

2. Georges Cuvier

Georges Cuvier lahir pada tahun 1769 di kota kecil Montbeliard yang berbahasa Prancis di daerah Wurttemberg, tidak jauh dari Prancis. Dia adalah putra kedua dari tiga bersaudara. Ayahnya perwira di ketentaraan dan keluarganya adalah penganut agama Kristen Lutheran yang sangat taat. 


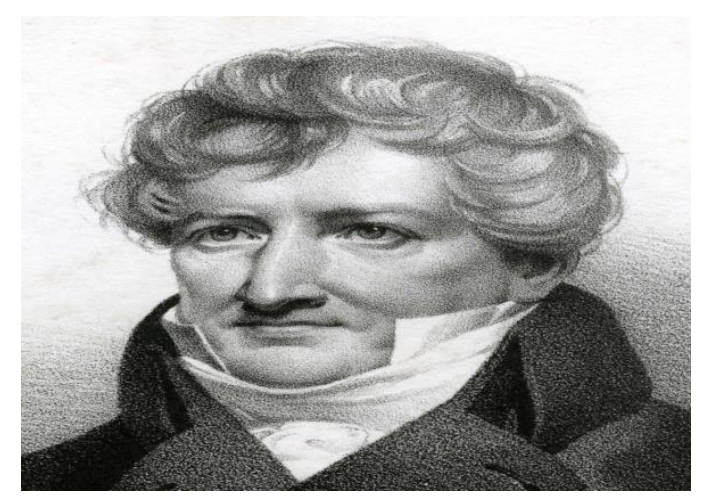

Gambar 5. Georges Cuvier

Minatnya terhadap zoologi dan botani telah tampak sejak dini. Dia menempuh pendidikan dasar di Montbeliard. la mempelajari zoologi dan botani. Kemudian dia bekerja sebagai pegawai pemerintah di sebuah kota kecil. Selama tujuh tahun di Normandi, Cuvier memanfaatkan waktu senggangnya untuk mempelajari tanaman dan hewan lokal, terutama hewan invertebrata di sepanjang pesisir. Sumbangan ilmiah besar yang diberikan Cuvier adalah bahwa dia "telah memantapkan ilmu anatomi perbandingan dan paleontologi." (Paleontologi adalah ilmu yang mempelajari fosil hewan, manusia, dan tumbuhan.) Dia juga memberikan sumbangan berarti untuk proses penggolongan hewan dan tumbuhan. Selama masa awal Cuvier di Museum Sejarah Alam, dia bekerja sama dengan Profesor Etienne Geoffroy Saint-Hilaire. Segera tampak bahwa pandangan Cuvier mengenai dunia hewan berbeda jauh dengan pandangan Geoffroy dan pakar biologi Prancis lain yang terkenal, Jean- Baptiste de Lamarck. Cuvier "beranggapan bahwa ciri-ciri anatomi yang membedakan kelompok hewan, membuktikan bahwa spesies tidak pernah berubah sejak masa kejadian. Setiap spesies begitu sempurna terkoordinasi, baik secara fungsi maupun secara struktur, sehingga tidak mungkin bisa bertahan menghadapi perubahan yang berarti." Maksudnya, Cuvier percaya bahwa hewan-hewan diciptakan dalam kelompok yang berbeda dan tetap, seperti dikatakan oleh Alkitab, Sebaliknya, "baik Lamarck maupun Geoffroy Saint-Hilaire mendukung gagasan bahwa semua hewan bisa disusun dalam "sebuah rantai besar makhluk" dari yang paling sederhana sampai yang paling rumit." Lebih lanjut, mereka juga percaya bahwa dengan berlalunya waktu, satu spesies bisa secara bertahap berevolusi menjadi spesies yang lebih tinggi. Lamarck mengatakan bahwa mekanisme yang memungkinkan terjadinya perubahan ini adalah "dipakai tidaknya berbagai anggota tubuh hewan." Lamarck juga percaya bahwa dalam dokumen fosil terdapat cikal- bakal hewan-hewan modern. Dalam perdebatan panjang tersebut, argumentasi paling kuat yang diajukan Cuvier adalah bahwa Lamarck tidak bisa membuktikan adanya transformasi spesies. Sedangkan Cuvier bisa menunjukkannya dari bukti- bukti yang dibawa kembali ke Prancis oleh tentara Napoleon. Bukti-bukti itu memperlihatkan bahwa hewan peliharaan tidak berubah sejak zaman Mesir kuno. Dia juga menunjukkan bahwa lenyapnya berbagai jenis hewan adalah karena hewan tersebut punah, bukan karena berubah menjadi spesies baru." Cuvier dengan tepat menunjukkan bahwa dokumen fosil justru menentang evolusi dan bukan mendukungnya. Dia mengatakan bahwa "jika spesies memang berubah secara bertahap, kita seharusnya bisa menemukan jejak perubahan itu; antara (fosil) paleotherium dan spesies yang ada sekarang seharusnya ada bentuk antara: tapi ini tidak pernah ada." Hingga sekarang hal ini masih belum terbantah, meskipun berjuta-juta fosil baru telah ditemukan sejak zaman Cuvier. Cuvier dan Lamarck juga tidak sepaham mengenai bagaimana kehidupan dimulai. Lamarck percaya adanya pemunculan spontan, yaitu bahwa kehidupan bisa berasal dari benda tak bernyawa. Namun, Cuvier menunjukkan bahwa "kehidupan selalu berasal dari kehidupan. Kita melihat kehidupan dialihkan tapi tidak pernah diciptakan." Sampai hari ini, tidak pernah ditemukan adanya kehidupan yang berasal dari yang non-hidup. Meskipun begitu, kaum evolusionis bersikukuh bahwa hal ini pasti 
pernah terjadi pada suatu saat. Anatomi perbandingan tidak membuktikan adanya hewan yang sedang dalam proses transformasi menjadi spesies lain, melainkan menunjukkan bahwa berbagai jenis hewan memiliki struktur yang serupa. Kaum evolusionis seringkali menyatakan, ini membenarkan keyakinan mereka bahwa satu jenis hewan bisa berubah menjadi hewan lain. Cuvier sendiri menolak gagasan keserupaan struktur tulang sebagai dasar pembenaran evolusi. Dalam mempelajari anatomi berbagai hewan, para ilmuwan kadang menemukan organ yang fungsinya tidak diketahui. Organ semacam ini dikenal sebagai "organ vestigial". Kaum evolusionis mengasumsikan bahwa organ- organ ini adalah sisa dari organ yang dulu berguna bagi nenek-moyang makhluk yang berevolusi. Meskipun Curier mengakui bahwa "organ vestigial ada dan karena itu harus dipelajari," dia tidak menganggap hal itu penting, karena dua alasan. Pertama, pada masa Cuvier tidak banyak ditemukan organ yang tidak jelas fungsinya. Kedua, Cuvier menganggap organ-organ itu sebagai "bagian penting dari Penciptaan, dan oleh karena itu keberadaannya pasti mempunyai alasan, sekalipun kita tetap tidak tahu." Cuvier yakin bahwa organ yang disebut "vestigial" bukanlah sisa-sisa evolusi yang tak ada manfaatnya, melainkan organ berguna yang masih belum diketahui fungsinya. Temuan ilmiah akhir-akhir ini membenarkan keyakinan Cuvier mengenai kegunaan organ-organ tersebut. Misalnya, ujung tulang belakang manusia (sering disebut sebagai tulang ekor) dulu dianggap sebagai sisa (yang tidak berguna) dari ekor monyet yang dianggap Sebagai nenek-moyang kita. Sekarang diketahui bahwa tulang itu adalah titik kaitan penting bagi otot-otot penopang tubuh dan isi perut kita. Contoh lain adalah amandel, yang dulu dianggap tidak berguna dan biasanya dibuang jika mengalami peradangan. Sekarang diketahui bahwa "amandel adalah alat penting untuk melawan penyakit. Seratus delapan puluh organ lain yang dulu dianggap tidak berguna dan hanya sebagai sisa evolusi saja, sekarang diketahui mempunyai fungsi penting."

3. Harun Yahya

Adnan Hoca atau Adnan Oktar merupakan ilmuan sekaligus seorang saintis asal Turki yang dikenal dengan nama pena Harun Yahya. Dia adalah seorang Creationisme yaitu orang-orang yang menentang teori evolusi.

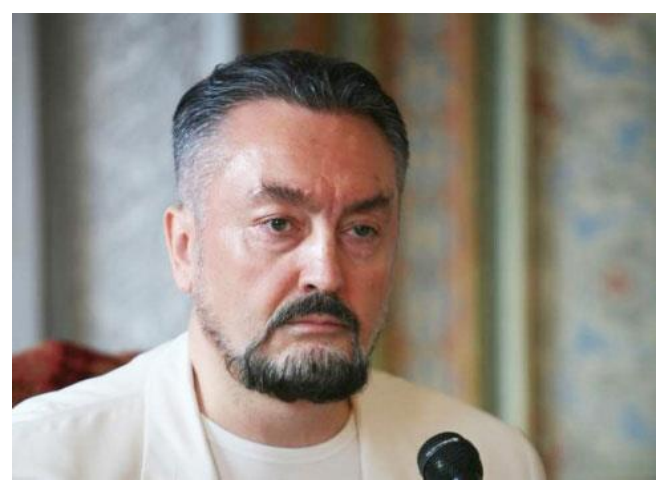

Gambar 6. Adnan Oktar

Orang-orang ini menganut paham tentang penciptaan dan percaya bahwa segala sesuatu yang ada dibumi ini bukan sebagai kebetulan semata. Mereka yang menganut paham ini adalah orang-orang yang tidak percaya akan evolusi makhluk yang terjadi antar spesies, bahwa spesies yang ada berasal dari hasil evolusi makhluk sebelumnya. Teori Penciptaan adalah pandangan dunia yang termotivasi secara keyakinan untuk menolak teori evolusi. Para pendukung penciptaan menyatakan bahwa struktur biokimia, morfologis dan pola-pola prilaku tidak dapat berkembang tanpa intervensi dari kekuatan supernatural (Nieminem, $R$ yokas \& Mustonen, 2015). didalam karyanya "Runtuhnya Teori Evolusi Harun yahya menulis bahwa berdasarkan catatan fosil, jika teori Darwin benar, maka seharusn ya pernah ditemukan spesiesspeies peralihan selama masa perubahan yang disebutkan sedemikian panjang hingga ratusan tahun. namun pada ken yataan ya semua bukti-bukti fosil yang ditemukan justru memberi bukti 
bahwa kehidupan dibumi ini ada secara tiba-tiba dan dalam kondisi yang lengkap dan utuh berdiri sendiri (tidak bercampur antar spesies sebagai bukti peralihan), seandainya teori Evolusi benar adanya, maka seharusnya akan ada ditemukan makhluk hidup transisi seperti ikan setengan reptil, dan bentuk- bentuk yang lain ya. Selama empat dekade terakhir, bio-kimia modern telah berhasil menyingkap rahasia sel. Hal ini menuntut puluhan ribu orang mendedikasikan bagian terbaik dari hidup mereka untuk pekerjaan laboratorium yang membosankan. Usaha kumulatif meneliti sel, yang berarti meneliti kehidupan di tingkat molekuler, menghasilkan sebuah kputusan tajam, jelas "Ini adalah desain". Hasilnya sangat signifikan, sehingga harus dikategorikan sebagai sebuah pencapaian terbesar dalam sejarah ilmu pengetahuan (Behe, 1996). Darwin sendiri sebenarnya mengalami kebimbangan pada pemikiranya yang la tuangkan dalam bukunya The Origin Of species. Darwin sendiri menyadari keraguan hatinya akan mendapati banyak kesulitan dari teorinya. la mengakui ini dalam tulisanya pada bab "Difficulties of the Theory". Kesulitan- kesulitan ini terutama pada penemuan akan catatan fosil dan organ-organ rumit makhluk hidup (misalnya mata) yang mustahil dijelaskan dengan konsep kebetulan dan naluri makhluk hidup. Darwin berharap kesulitan-kesulitan ini akan teratasi oleh penemuan-penemuan baru,akan tetapi pada akhirn ya Darwin tetap memberikan sejumlah penjelasan yang sangat sederhana untuk menjelaskan sebagian kesulitan itu. Hal yang paling meragukan adalah belum ditemukanya makhluk transisi dari pada setiap perubahan yang terjadi antar spesies. Hal inilah yang kemudian memunculkan konsep missing link atau garis keturunan yang hilang (Mardikaningsih, 2013).

\section{PENUTUP}

Fakta - fakta pemikiran manusia dituangkan dalam deskripsi maupun teori diberbagai tulisan yang menginspirasi generasi yang bersisian maupun setelahnya. Teori akan menjadi sebuah kebenaran ilmiah ketika dapat dibuktikan melalui fakta eksperimen (Firman, 2016). Demikian pula para ahli dan ilmuan yang diungkap dalam fakta sejarah diatas. Ada banyak pandangan yang bergolak sejak mulai dari pencetusan istilah evolusi hingga masa sekarang. Akan tetapi setiap argument memiliki bukti-buktinya sendiri. Ilmu evolusi akan terus menerus berkembang dan mengalami banyak fase, bisa jadi akan mendapatkan titik temu atau tetap dalam kontroversi. Kita berasal dari satu sel yang tunggal atau kita diciptakan utuh sebagai bukti ajaib penciptaan Tuhan, semua kembali kepada bagaimana anda memandang dan sejauh mana anda memiliki pengetahuan. Akan tetapi harus diingat bahwa kita harus tetap berpijak pada bukti ilmiah untuk menuntun keyakinan kita pada kebenaran sebuah pernyataan.

\section{DAFTAR PUSTAKA}

Behe, Michael J., 1996. "Darwin's Black Box”. Newyork: Freepress.

Coyne, Jerry A., 2009. "Why Evolution Is True". New York: Penguin Group

Campbell, N.A., Reece, J.B., dan Nitchel, L.G., 2003. Biologi: Edisi Kelima Jilid. 2.

Firman, Harry., 2016. "Metode IImiah". https://www.academia.edu/31489325/METODE ILMIAH (Diunduh 16 April 2017)

Coyne, Jerry A., 2009. "Why Evolution Is True”. New York: Penguin Group

Lindsay, M.B., Petto, A.J., \& Benjamin, C., 2014. "Evolution: education \& Outreach". USA: Springer

Nieminem. 2015. "Experiential Thining In Creation-A Textual Analysis". Finland: PLOSone

Park, Michael A., 2012. "Exploring Evolution". London: Vivays Publishing 
Snobelen, 2001. Men and Angels: The Competing Myth of Isabelle Duncans Pre-Adamite Man (1860). United Kingdom: Elsavier. Volume 2 No.1

Sugiri, N., 1988. "Hakiki Evolusi”. Bogor: PAU IPB Kaufman, W.R., 2014. 